\title{
The Views of Pre-Service Science Teachers on the History of Science After Taking the Course of the Course of Nature and History of Science: A Profile from Turkey
}

\author{
Ibrahim Yuksel ${ }^{1} \&$ Merve Eker $^{1}$ \\ ${ }^{1}$ Department of Mathematics and Science Education, Gazi University, Ankara, Turkey \\ Correspondence: Ibrahim Yuksel, Department of Mathematics and Science Education, Gazi University, Ankara, \\ Turkey. E-mail: ibrahimyuksel7@hotmail.com
}

Received: April 28, 2020

Accepted: December 29, 2020

Online Published: March 28, 2021

doi:10.5539/ies.v14n4p72

URL: https://doi.org/10.5539/ies.v14n4p72

\begin{abstract}
This study aims to determine the knowledge levels in the Nature and History of Science course of the prospective teachers studying in the science education program and their views following the course. Six interview questions were asked to the pre-service teachers in the science education program about the Nature and History of Science course. Seventy-nine pre-service teachers studying at a state university's Faculty of Education Department of Science Education who took the Nature and History of Science course in the 2018-2019 academic year participated in this study voluntarily. Case study, one of the qualitative research designs, was used in this study. Case study is a research method that identifies an event or phenomenon within the framework of natural real life, and examines situations in a multifaceted, systematic and detailed manner (Yildirim \& Simsek, 2013). The characteristics of qualitative research are based on the main emphasis, process, understanding and meaning. The researcher is the main determinant in data collection and analysis, the process is inductive, and the product should be detailed and extensive (Merriam, 2013). Data were collected through interview questions developed by the researchers on the Nature and History of Science course. According to data analysis and the views of the prospective teachers, the highest 3 frequencies for the first question are as follows: 'Scientific information does not change. Hypotheses are developed into theories and theories are developed into laws. There is only one scientific method that is universally accepted in science.' In the second question, the pre-service teachers named the first 5 scientists with whom they were most impressed were as Aziz Sancar, Albert Einstein, Tesla, Avicenna and Newton. As for the third question, the view mostly emphasized by the pre-service teachers on the inclusion of the Nature and History of Science course among the secondary school courses was that scientific information is not easy to reach and how to reach it should be taught. Another view was that the importance of science should be taught at an early age. The fourth question was asked to the participants to reveal the techniques/methods they will use to teach the nature of science when they actively start to work as teachers. The responses were inquiry-based teaching and constructivist learning approach along with teaching through demonstration and brainstorming. In the fifth question, while explaining the relationship between the history of science and nature of nature for science-literate individuals, pre-service teachers expressed an opinion that it is easier to understand the nature of science if it is based on the history of science, that the nature of science contains the history of science, and that the history of science and the nature of science nurture and support each other. The sixth question aimed to reveal additional views of the teacher candidates on the nature and history of science course. The responses were as follows: 'I consider it adequate', 'It may be more intriguing and interesting', and 'The importance of science should be taught at an early age.'
\end{abstract}

Keywords: scientist, the history of science, science candidate teachers and their views

\section{Introduction}

The constantly changing and evolving structure of science necessitates transferring science to daily life instead of being known only as information. For this reason, it becomes important to educate individuals who use scientific information and understand the nature of science in contemporary education systems. Among the individuals who understand the nature of science as well as scientists are science teachers and prospective science teachers. The development of science teachers and prospective teachers in the field regarding the nature of science contributes to the training of their students as individuals with an sense of the nature of science. Teachers and pre-service teachers 
are individuals who raise awareness about the nature of science, create and develop scientific information, and enlighten them to produce new information using their productions (Cakici, 2009). Erdas-Kartal and Ada (2018) found that the majority of preschool prospective teacher had insufficient knowledge and misconceptions about the nature of science. It is likely to say that the nature of science can be attained by the students in this way better science-literate individuals who can inquire better, question and solve the problems encountered in daily life can be educated. However, it is likely to see in the related literature that there are misconceptions in the understanding of teachers and students about the nature of science (Lederman, 1992). Yenice and Atmaca (2017) aimed to determine the knowledge and views of prospective science teachers about the nature of science and scientific information. The case study, which is one of the qualitative research designs, was conducted with 43 prospective teachers studying in the Department of Science Education of a Faculty of Education in the Aegean region. The Views of Nature of Science - Form C (VNOS-C) questionnaire was used in the study. At the end of the research, it was found that there were some mistakes, misconceptions in the views of the prospective science teachers about the nature of science, but they were mostly 'partially acceptable'.

When teachers become aware of misconceptions before teaching the nature of science, it will be easier to change these misconceptions and adopt current concepts (Abd-El-Khalick \& Lederman, 2000). Better results can be achieved if we teach the nature of science through the history of science.

When students are not given the opportunity to relate a historical example to the belief in the nature of science concerned, they will not see these examples as interesting and enlightening. When rich historical chapters are included in teaching, humanization of science as an exciting human adventure can be achieved (McComas, 2008).

The reasons identified by Matthews (2017, p. 162) for the inclusion of the history of science in the curriculum are given below.

- History contributes to the understanding of scientific methods and concepts.

- Historical approaches provide the connection between the development of individual thought and the development of scientific ideas.

- History of science is intrinsically valuable; students should be familiar with important events in science history and culture.

- History of science is necessary to understand the nature of science.

- History examines the age of scientists, humanizing the subject of science, making it more tangible and attractive for students.

- History provides links between science disciplines and other academic disciplines as well as the subject headings; history reveals the independent and complementary nature of man.

Throughout history, people's needs have changed in terms of environment, culture and conditions. These growing requirements have led the efforts of human beings to understand nature, find solutions to natural phenomena and resist them. The efforts of humanity to dominate nature are as old as human history. The need to understand nature dates way back as well. Science began to emerge with the combination of these two demands (Yildirim, 2006). It is the history of science that examines these efforts of human being and the processes of development of scientific information. Upon the close examination of the emergence of this history, it is likely to see that it appeared with the emergence of the human species as a result of their needs and efforts, and showed a rapid development (Topdemir \& Unat, 2008). In Egypt and Mesopotamia, where the first scientific activities were known to have existed, these activities were well organized and recorded in line with the needs of the society for practical purposes. This, in turn, led to permanent information. Then, with the Greek period, the need to understand the universe emerged. The Greek preferred to do philosophy of nature instead of looking for practical solutions (Yildirim, 2006). Following the ancient Greek period, the millennium period until the beginning of the Renaissance in Europe was the medieval period. In this period, Muslims dominated science and philosophy. The studies of Muslim scholars in the fields of science and philosophy led to the reformation of scientific thought in Europe (Alkan, 2009). The period of the Middle Age is followed by the Modern Age. In this period, it was argued that science had to be based on observation and experiment and these scientific methods formed the origin of the studies (Topdemir \& Unat, 2008).

Abd-El-Khalick and Lederman (2000) investigated the impact of the history of science course on prospective teachers and university students' views on the nature of science. Within the scope of this research, they reached 15 pre-service teachers and 166 students. The views of the participants before and after the application were collected through individual interviews and an open-ended questionnaire. Almost all participants were found to be insufficient in some items related to the nature of science prior to the application. At the end of the application, it 
was concluded that there were few and limited changes in the views of the participants. The researchers emphasized that some features related to the nature of science should be taken into consideration when applying the history of science and that the training of the participants about the nature of science could be effective before the application.

Being science-literate means being able to understand the concepts of science, have a good command of science and nature, form scientific arguments, develop research and evaluation skills. Therefore, teaching the nature of science starting from elementary education onwards in science education can enable the spread of science literacy (Tasar, 2002). The nature of science, which is a dimension of science literacy, has been one of the most frequently studied subjects in recent years by science educators, science historians, sociologists and philosophers. The inclusion of the nature of science into the science curriculum may enable students to understand the products of science and its applications in everyday life. At the same time, learning the characteristics of science correctly will give students who will become active citizens in country policies in the future both scientific thinking and problem-solving skills (Aliyazicioglu, 2012).

\subsection{Aim of Study}

In science education, research on the nature of science has generally focused on measuring the understandings of students and teachers, improving these understandings and evaluating the impact of teaching approaches for improvement. However, the desired objectives regarding the nature of science have not yet been achieved. Upon the review of the literature, it is likely to see that students and teachers are still insufficient in some aspects with regard to the nature of science (Abd-El-Khalick et al., 2017). In order to overcome these insufficiencies, the nature of science should be well understood (Doruk, 2018).

This study intends to surmount the characteristics of the nature of science following the history of science applications by prospective science teachers and determine their views on the nature of science prior to the application.

Prospective teacher were asked 6 interview questions about the development of science. For this purpose, the research questions were arranged as follows:

1) Write 5 misconceptions about the Nature and History of Science course. Please explain.

2) Write the scientists (at least 5) you are most impressed with. Why?

3) Should the Nature and History of Science course be among the main courses in secondary schools? Why? Why not?

4) Which approach would you prefer to teach the nature of science when you become a teacher? Why?

5) What kind of relationship do you think there is between the history of science and the nature of science for science-literate individuals?

6) What would you like to add about the Nature and History of Science course?

\section{Method}

In this study, case study design, one of the qualitative research designs, was used. Case study is a research method that identifies an event or phenomenon within the framework of natural real life, and examines situations in a multifaceted, systematic and detailed manner (Yildirim \& Simsek, 2013). The characteristics of qualitative research are based on the main emphasis, process, understanding and meaning. The researcher is the main determinant in data collection and analysis; the process is inductive; product should be described in detail and rich (Merriam, 2013). In this research, qualitative data were obtained through interviews. Interviewing is a technique of collecting verbal information on the subject under discussion and is usually conducted face to face. Interviews can be used in many ways, such as surveys and observation. Interviews provide in-depth information about a particular research topic or a question (Kincal, 2015).

\subsection{Study Group}

The study was conducted with 79 prospective teachers who were randomly selected in the Department of Science Education in the Faculty of Education of a state university in the spring semester of the 2018-209 academic year. This sampling method is working with a homogenous subgroup related to the problem of research from the population (Buyukozturk, Cakmak, Akgun, Karadeniz \& Demirel, 2014). Homogenous sampling selection was used in this study since it includes candidate teachers taking the same course, having homogenous characteristics and chosen from the population. The prospective teachers in the study were coded as PT1, PT2, PT3 ...... PT78 and PT79. 
Table 1. Demographic information on gender

\begin{tabular}{ccc}
\hline Gender & $\mathrm{N}$ & $\%$ \\
\hline Male & 8 & 10.1 \\
Female & 71 & 89.9 \\
\hline
\end{tabular}

\subsection{Data Collection Tools}

Interview questions developed by the researchers were used as the main data collection tool in this case study. Research data were obtained through literature review and interview questions examined and developed by researchers based on the opinions of three experts in the field of studies on the subject in Turkey. In order to form the interview questions of the study, the literature was reviewed and the studies about the subject were examined. So as to reach the aims determined in this research, interview questions over the nature and the history of science course developed by the researcher for teacher candidates were used as data collection tool. In the current study, semi-structured interview method, one of the qualitative data collection tools, was used because it aimed to reveal the views of teachers. The semi-structured interview method provides the opportunity to ask in-depth questions about a specific topic, repeating questions in unclear situations, making them more descriptive and offering to complete the answers (Cepni, 2010). The related literature was reviewed and a pool of 11 questions was created. Six questions were developed for the nature and history of science course as interview questions for the written interview formed depending on the opinions of 3 experts specialized in the field. The questions in the interview form were developed in accordance with the opinions of 3 experts in the field and the content validity was ensured. Each interview lasted 20-30 minutes. With the consents granted, the views of the prospective teachers were written on the interview form paper during the interviews.

\subsection{Data Analysis}

Content analysis was performed in the analysis of the data. Content analysis is a method usually used in the analysis of written and visual data. This method follows a deductive path. In content analysis, the researcher primarily develops categories related to the research topic. Categories are counted as words, sentences or visuals. At the stage of category development, attention should be paid to developing appropriate categories in which other researchers who plan to conduct a similar research through the same text can achieve the same results (Ozdemir, 2010). The main purpose of content analysis is to reach concepts and relationships that can explain the collected data. Accordingly, it is necessary to first conceptualize the collected data and then rationally organize the emerging concepts and identify the themes explaining the data accordingly. Thus, it is aimed to identify the data obtained through content analysis and reveal the facts hidden in the data (Yildirim \& Simsek, 2013).

In the current study, the following steps were followed when analyzing the data: Interview questions in the data obtained were turned into a text by two experts without any changes. Afterwards, the texts were examined one by one and care was taken to avoid any inconsistencies. In the light of the statements of the participants, some codings were created in accordance with the purpose of the study. In order to ensure inter-coder reliability, 112 codings were made in the common vision. Disagreement was identified in seven codings. Inter-coder reliability was calculated by dividing the number of agreed codings by the total number of agreed and disagreed codings. The inter-coder reliability, recommended to be more than $90 \%$, (Miles \& Huberman, 1994) was $94 \%$. Codings were created by providing themes to sub-problems.

\subsection{Findings}

In this section, the responses of the pre-service teachers to the interview form about the status of the course of Nature and History of Science at the end of the semi-structured interviews, the frequency values of these answers and the views of some randomly selected prospective teachers are given.

In the first question, the candidate teachers were asked to write 5 misconceptions about the nature and the history of science course and explain them. The responses of candidate teachers to this question are given in Table 2 under the theme of misconception. 
Table 2. Views and frequencies on the theme of misconceptions

\begin{tabular}{lc}
\hline Codings & $\mathrm{f}$ \\
\hline Scientific information does not change. & 39 \\
Hypotheses are developed into theories and theories are developed into laws. & 37 \\
There is only one scientific method universally accepted in science. & 20 \\
Scientific information can only be accessed by experiment. & 15 \\
Laws cannot be changed. & 13 \\
Science answers every question. & 13 \\
Scientists are completely objective, not affected by social and cultural values. & 9 \\
Scientific information is objective. & 6 \\
Theories and laws are the same. & 5 \\
There is a hierarchical order between hypothesis, theory and law. & 3 \\
Case and phenomenon are the same. & 1 \\
Scientists are superior to normal people. & 1 \\
\hline Total & 162 \\
\hline
\end{tabular}

As is given in Table 2, there are 12 codings containing views of the prospective teachers over the theme of misconception. The most important misconception that prospective teachers emphasized about the misconceptions in the nature and history of science course was that 'Scientific knowledge does not change' and the second was 'Theories are developed by hypotheses and the theories are converted into laws'.

The views of some prospective teachers regarding question 1 are given below:

PT9: "There's a misconception of the fact that laws never change. Theories are supposed to turn into laws over time. There are many misconceptions about what theory and law are. Scientific information is thought to never change."

PT29: "It is assumed that there is a hierarchical relation between hypothesis, theory and law, but it is wrong. There is no hierarchical relation and they do not convert into one another. Scientific information is considered to be objective. However, the process of creating scientific information is subjective. Scientific information, that is, the product is objective. Scientists are not entirely objective. They can be subjective in terms of their culture and beliefs. Scientists are perceived as superior and divine people; they are individuals who think and examine more."

PT58: "Information is unchangeable. When theories are confirmed, they become laws. Scientists are purely objective. There is only one scientific method. Scientists have found the cause of everything."

In the second question, the prospective teachers were asked to write the names of the scientists with whom they are influenced most and explain why. Prospective teachers' responses to this question are given in Table 3 under the theme of the scientists you are most impressed with.

Table 3. Views and frequencies about the most influenced scientists

\begin{tabular}{lcll}
\hline Codings & f & Codings & f \\
\hline Aziz Sancar & 35 & Descartes & 3 \\
Albert Einstein & 35 & Ömer Hayyam & 3 \\
Tesla & 27 & Zehravi & 3 \\
Avicenna & 26 & Mendel & 3 \\
Newton & 22 & Ibn Nefs & 3 \\
Galilei Galileo & 19 & Graham Bell & 3 \\
Al-Farabi & 16 & Socrates & 3 \\
Aristothales & 14 & Roger Bacon & 3 \\
Ibn al-Haytham & 12 & Maxwell & 2 \\
Ali Kuşçu & 11 & Ibn Cessar & 2 \\
Kepler & 10 & Michael Faraday & 2 \\
Copernicus & 10 & Lavoiser & 2 \\
Biruni & 9 & Pavlov & 2 \\
Harezmi & 9 & Canan Dağdeviren & 2 \\
Edison & 9 & Toricelli & 2 \\
Stephen Hawking & 7 & Cahit Arf & 2 \\
\hline
\end{tabular}




\begin{tabular}{lllc}
\hline Akşemseddin & 6 & Battani & 1 \\
Marie Curie & 6 & Mimar Sinan & 1 \\
Fuat Sezgin & 5 & Halil İnancik & 1 \\
Jabir Bin Hayyam & 5 & Hazerfen Ahmet Çelebi & 1 \\
Pisagor & 4 & Harvey & 1 \\
Plato & 4 & Ptolemy & 1 \\
Al Cezeri & 4 & Hubble & 1 \\
Pasteur & 4 & Ibn Baytar & 1 \\
Pascal & 4 & Avogadro & 1 \\
Elon Musk & 4 & Democritos & 1 \\
Darwin & 3 & Volta & 1 \\
\hline Total & & & 370 \\
\hline
\end{tabular}

As given in Table 3 there are 54 codings that contain views of prospective teachers over the theme of the scientists they are most impressed with. The first 5 scientists that the teacher candidates expressed they were most impressed with were Aziz Sancar, Albert Einstein, Tesla, Avicenna and Newton.

The views of some prospective teachers regarding question 2 are given below:

PT3: "With the technology of that time, Newton reached the laws that are still applied from the past to the present."

PT30: "Nikola Tesla dedicated his life to many experiments and inventions to meet the needs of people. He preferred science to money. He never considered his own interests."

PT58: "Einstein made a breakthrough in physics."

PT74: "Avicenna's studies on modern surgery were instrumental in saving people's lives."

PT76: "Aziz Sancar made us proud of his Nobel Prize and his work is of interest to me."

The teacher candidates were asked, in the third question, whether the nature and history of science course should be included among the courses of secondary schools and to state the reason why. The responses of prospective teachers to this question are shown in Table 4 on the theme of the nature of science in secondary school courses.

Table 4. Views and frequencies on the theme of the nature of science in secondary school courses

\begin{tabular}{lc}
\hline Codings & $\mathrm{f}$ \\
\hline Scientific information is not easy to reach and how to reach it should be taught & 17 \\
The importance of science should be taught to students at an early age. & 17 \\
Students become curious about science and their interest increases. & 13 \\
Students get to know scientists and take them as role-models. & 11 \\
The imagination of the students increases and their horizon expands. & 9 \\
It must be included. & 9 \\
It is necessary to educate science-literate and qualified individuals. & 8 \\
They learn how to contribute to science. & 7 \\
Students should get to know the inventors of inventions. & 7 \\
Students develop their thinking and anticipation skills. & 2 \\
It should be taught in an entertaining way. & 1 \\
\hline Total & 101 \\
\hline
\end{tabular}

As is given in Table 4, there are 11 codings having the views of prospective teachers over the nature of science lesson theme in secondary school courses. The predominantly expressed views by the prospective teachers on the inclusion of the nature and history of science course among secondary school courses were that scientific information is not easy to reach and how to reach it should be taught, and that the importance of science should be taught students at an early age.

The views of some prospective teachers regarding question 3 are given below:

PT41: "It could be. They are better able to follow and notice the current developments. Perhaps you can inspire them with these inventions." 
PT60: "It is important for our future to tell our history at an early age that scientists have contributed to science with what kind of difficulties and at what stages. The nature and the history of science course plays an important role in leading a person to engage in science and making them successful."

PT70: "Since the understanding of the nature of science is a way of understanding science, it should be taught in secondary schools. In addition, the nature and the history of science should be among the main subjects as children can be more curious about science by learning the development and the birth of the science since it is in every field of our life."

The teacher candidates were asked in the fourth question what teaching approaches they would prefer to use in teaching the nature of science when they became teachers and explain why. The prospective teachers' responses to this question are given in Table 5 under the theme of teaching approaches to the nature of science.

Table 5. Views and frequencies on the theme of approaches to teaching the nature of science

\begin{tabular}{lc}
\hline Codings & $\mathrm{f}$ \\
\hline Inquiry-based teaching & 9 \\
Constructive learning approach & 9 \\
Teaching by demonstration & 6 \\
Brainstorming & 6 \\
Problem solving & 4 \\
Discovery & 4 \\
Experiment & 4 \\
Role-play & 4 \\
Collaborative learning & 4 \\
Formative learning approach & 4 \\
Project-based & 3 \\
Creative drama & 3 \\
Prediction-observation-explanation & 2 \\
Learning by doing & 2 \\
Question-answer & 1 \\
Observation & 1 \\
\hline Total & 66 \\
\hline
\end{tabular}

As is given in Table 5, there are 16 codings that contain the views of prospective teachers about the theme of approaches to teaching the nature of science and the frequencies. They stated that they would use primarily inquiry-based teaching and constructivist learning approach and secondarily teaching by demonstration and brainstorming techniques to teach the nature of science when they became teachers.

The views of some prospective teachers regarding question 4 are given below:

PT50: "I will use the constructivist learning approach. Thanks to the constructivist learning approach, I will correct the misconceptions of the students by taking into consideration the previous knowledge of the children and enable them to establish a relationship between the previous knowledge and the new knowledge."

PT57: "I would prefer the inquiry-based teaching approach. Because in this approach, students reach information on their own, and information becomes more permanent thus they learn to think scientifically."

The prospective teachers were asked, in the fifth question, what kind of relation there is between the nature of science and the history of science for science-literature individuals. The responses of prospective teachers to this question are given in Table 6. 
Table 6. Views and frequencies on the relationship between science literacy and history of science and nature of science

\begin{tabular}{lc}
\hline Codings & $\mathrm{f}$ \\
\hline It becomes easier to understand the nature of science in association with the history of science. & 17 \\
The nature of science contains the history of science. & 11 \\
The history of science and the nature of science nurture and support each other. & 10 \\
They both deal with the history of science. & 1 \\
\hline Total & 39 \\
\hline
\end{tabular}

As is given in Table 6, four codings draw attention regarding the views of prospective teachers over the theme of the relation between the nature and the history of science and science-literacy. The most emphasized views by the prospective teachers were that "it becomes easier to understand the nature of science basing it on the history of science", that "the nature of science contains the history of science", and "the history of science and the nature of science nurture and support each other".

The views of some prospective teachers regarding question 5 are given below:

PT29: "A science-literate individual wants science to develop and accumulate. Knowing the history of science enables us to understand scientists and scientific discoveries."

PT52: "In fact, the history of science and the nature of science are intertwined concepts that follow one another. On the one hand, the history of science may coincide upon looking at the nature of science."

PT74: "We try to understand the nature of science through the events of the past in the history of science. Science has an open structure to continuous change. We can observe the development of science more easily from the history of science."

In the sixth question, the teacher candidates were asked about their additional views on the nature and history of science course. Their responses to this question along with the theme of additional views on the nature and history of science course are presented in Table 7.

Table 7. Views and frequencies of additional views on the course of nature and history of science

\begin{tabular}{lc}
\hline Codings & $\mathrm{f}$ \\
\hline I consider it sufficient. & 16 \\
It can be more intriguing and interesting. & 6 \\
Simple experiments can be done about the work of scientists, videos can be watched and materials can be used. & 4 \\
Tesla, Edwin Hubble and Edsger Dijkstra can be added into related subjects. & 3 \\
The lives of scientists can be included more. & 2 \\
Topics can be more related to everyday life. & 2 \\
Topics can be explained shorter. & 2 \\
Trips to science centers can be arranged. & 2 \\
Subjects can be taught through slides. & 1 \\
A more understandable book can be used. & 1 \\
Today's scientists and scientific studies should be included. & 1 \\
It may be better to teach subjects through storytelling. & 1 \\
Turkish-Islamic thinkers can be included more. & 1 \\
The golden age which is called the dark age can be emphasized more. & 1 \\
The nature of science and the history of science can be described in relation. & 1 \\
\hline Total & 44 \\
\hline
\end{tabular}

As is shown in Table 7, there are 15 codings regarding the additional views of propsective teachers over the nature and history of science course. The prospective teachers' mostly stressed views were that 'I consider it sufficient', 'It can be more intriguing and interesting', and 'The importance of science can be taught students at an early age' respectively.

The views of some prospective teachers regarding question 6 are given below:

PT1: "It can be effective to arouse curiosity by including scientists'lives more." 
PT31: "The elements of the nature of science should be clearly explained to the students. By giving examples from daily life, the subject should not be taught by heart."

PT77: "More visual materials and videos can be used in the lessons and drama can be done for students to understand better."

\section{Conclusion and Discussion}

The misconceptions put forward by the prospective teachers were revealed by the prospective teachers as factors that made it difficult for them to learn in the nature and history of science course. Accordingly, for all sub-dimensions of the nature of science, prospective teachers emphasized the misconceptions in the literature and stated that it might be difficult to learn the nature of science. Misconceptions with the highest frequency are as follows: Scientific information does not change. Hypotheses are developed into theories and theories are developed into laws. There is only one scientific method that is universally accepted in science. Scientific information could be changed by reinterpreting new or existing observations. This is a logical justification for the fact that all elements of the nature of science are subject to change (Schwarzt, Lederman, \& Crawford, 2004). In his study, Polat (2011) stated that for prospective teachers, scientific information is absolutely correct and they accept this information free from errors. Scientific information is reliable but never absolute or definitive. Laws and theories are also subject to change (Lederman, Abd-El-Khalick, Bell, \& Schwartz, 2002). Since it is difficult to change misconceptions, it is true that it is quite difficult for students to develop their views on the nature of science, some established beliefs and misconceptions. To address these, teaching the nature of direct reflective science should be implemented using activities integrated into the science curriculum, starting at primary level. Using the history of science and philosophy of science in these lectures will reinforce the understanding of the nature of science. In science classes, presenting sections of the daily lives of scientists and talking about their working styles will give students an idea about the functioning of science, and enable them to empathize with scientists and become interested in science (Atac-Ozdemir, 2017).

In a study carried out with prospective science teachers, Sert-Cibik (2016), investigated the effect of traditional method on the nature of science with project-based learning approach based on the history of science and the nature of science. With 41 participants in the experimental group and 46 in the control group, this study was designed according to a quasi-experimental model with unequaled control group. At the end of the study, a significant difference was found in favor of the experimental group and it was observed that the students in this group reshaped their views on the nature of science and eliminated the current misconceptions.

The first 5 scientists that the teacher candidates said they were most impressed with were Aziz Sancar, Albert Einstein, Tesla, Avicenna and Newton. The reason why Aziz Sancar is mentioned in the first place is that he won the 2015 Nobel Prize in Chemistry for his research that maps how cells repair damaged DNA and preserves their genetic information, and this is a current issue. Their mostly stressed view on the inclusion of the nature and history of science course among the courses of secondary schools was that scientific information is not easy to reach and how to reach it should be taught. Another view was that the significance of science should be taught at an early age. It was pointed out that primarily inquiry-based teaching and constructivist learning approach and secondarily teaching by demonstration and brainstorming techniques would be preferred by the prospective teachers of science in teaching the nature and history of science course when they became teachers.

In another study, Cansiz (2014) examined the impact of history of science-based science teaching on science literacy and science attitudes of 6th graders. The study was conducted with 95 secondary school students from 4 different classes and two experimental groups and two comparison groups were randomly assigned. In the experimental group, the history of the circulatory system was integrated into the curriculum, and in the comparison group, the same subject was taught in accordance with the curriculum. At the end of the research, it was shown that science teaching based on the history of science was more successful than the curriculum-based teaching in terms of developing science literacy and positive attitude towards science.

The views that were mostly expressed by the prospective teachers regarding the relation between the nature of science and history of science for science-literature individuals were that it becomes easy to understand the nature of science when it is based on the history of science, the nature of science involves the history of science, and the nature of science and the history of science nurture and support each other. The history of science and the nature of science will save science education from being mono-dimensional, develop a positive attitude towards science in students, contributing to individuals becoming science literate (Monk \& Osborne, 1997).

The views on the nature and history of science course additionally expressed by the prospective teachers were that they consider it sufficient, that it could be more intriguing and interesting, and that the importance of science should be taught at an early age. Abd-El-Khalick and Lederman (2000) investigated the effect of history of science 
course on the views of prospective teachers and university students over the nature of science. The participants were 166 undergraduate and graduate students and 15 secondary school prospective science teachers. Open-ended questions were used before and after the research to assess the nature of science. It was found that the participants were insufficient in terms of the nature of science before application. After 10 weeks of history of science lessons, it was concluded that there was little and limited change in the opinions of the participants. The fact that there is little or limited change in the views of the participants might be due to insufficient emphasis on the nature of science in the teaching of history of science.

\section{Limitations and Suggestions for Future Studies}

The current study was conducted with prospective science teachers. Similar studies could be conducted with science teachers and secondary school students. While the interview questions were limited to 4 weeks, it could be extended with the participation of more people for longer periods. In pre-service education, similar studies could be carried out with prospective science teachers and other disciplines such as physics, chemistry and biology.

\section{References}

Abd-El-Khalick, F., \& Lederman, N. G. (2000). The influence of history of science courses on students' views of nature of science. Journal of Research in Science Teaching. The Official Journal of the National Association for Research in Science Teaching, 37(10), 1057-1095. https://doi.org/10.1002/1098-2736(200012)37:10<1057::AID-TEA3>3.0.CO;2-C

Abd-El-Khalick, F., Myers, J. Y., Summers, R., Brunner, J., Waight, N., Wahbeh, N., .. Belarmino, J. (2017). A longitudinal analysis of the extent and manner of representations of nature of science in US high school biology and physics textbooks. Journal of Research in Science Teaching, 54(1), 82-120. https://doi.org/10.1002/tea.21339

Aliyazicioglu S. (2012). Bilimin doğası ögretiminde bütüncül bir yaklaşım: Farklı branşlardan öğretmenlerin bilimin doğası algllarl [Holistic approach in teaching of nature of science: Teachers' perception of nature of science from different branch] (Master's Thesis, Marmara University, İstanbul).

Alkan, N. (2009). Tarihin çağlara ayrılmasında "üç”lü sistem ve "Avrupa merkezci” tarih kurgusu [The "Triple system" at the periodization of history and the question of Turkish-Islamic historical periodization]. Turkish History Education Journal, 2(9), 23-42.

Atac-Ozdemir I. B. (2017). Bilimin doğası ve bilimsel tartışma ile birleştirilmiş bilimin doğası eğitiminin lise 10. sinıf öğrencilerinin bilimin doğası anlayışları, tartışma becerileri ve kimya dersine karşı tutumları üzerine etkilerinin karşılaştırılması [Comparison of the effects of explicit nature of science instruction and explicit nature of science instruction integrated with explicit argumentation instruction on grade 10 students' nos understandings, argumentation skills and attitudes towards chemistry] ( $\mathrm{PhD}$ Thesis, Marmara University, Istanbul).

Cakici, Y. (2009). Fen eğitiminde bir ön koşul: Bilimin doğasını anlama [A prerequisite in science education: Understanding nature of science]. Marmara University Atatürk Education Faculty Journal of Educational Sciences, 29, 57-74.

Cansiz, M. (2014). Bilim tarihi eğitiminin ortaokul öğrencilerinin fen okuryazarligina etkisi [The effect of history of science instruction on elementary students' scientific literacy] (PhD Thesis, Middle East Technical University, Ankara).

Cepni, S. (2010). Araştırma ve Proje Çalışmalarına Giriş [Introduction to Research and Project Studies] (5th ed.). Trabzon.

Doruk, O. (2018). Bilim tarihi temelli fen ögretiminin sınıf ögretmeni adaylarının fen öğretimine yönelik tutumlarına ve bilimin doğası inanışlarına etkisi [The effect of history based science teaching on class teacher candidates' science teaching attitudes and the nature of science beliefs] (Master's thesis, Gazi University, Ankara).

Erdas-Kartal, E., \& Ada, E. (2018). Okul öncesi öğretmen adaylarının bilimin doğası hakkındaki anlayışları [Understandings of Preschool Candidate teachers about Nature of Science]. Cumhuriyet International Journal of Education, 7(1), 84-101. Retrieved from https://dergipark.org.tr/tr/pub/cije/issue/36602/384055

Kincal, R. (2015). Bilimsel Araştırma Yöntemleri [Scientific Research Methods] (4th ed.). Ankara: Nobel Publications.

Lederman, N. G. (1992). Students' and teachers' conceptions about the nature of science: A review of the 
research. Journal of Research in Science Teaching, 29, 331-359. https://doi.org/10.1002/tea.3660290404

Lederman, N. G., Abd-El-Khalick, F., Bell, R. L., \& Schwartz, R. S. (2002). Views of nature of science questionnaire: Toward valid and meaningful assessment of learners' conceptions of nature of science. Journal of research in science teaching, 39(6), 497-521. https://doi.org/10.1002/tea.10034

McComas, W. F. (2008). Seeking historical examples to illustrate key aspects of the nature of science. Science \& Education, 17(2-3), 249-263. https://doi.org/10.1007/s11191-007-9081-y

Merriam, S. B. (2013). Nitel araştırma [Qualitative research] (ed. Selahattin Turan). Ankara: Nobel Publications.

Miles, M. B., \& Huberman, A. M. (1994). An Expanded Sourcebook: Qualitative Data Analysis (2nd ed.). ThoAbdnd Oaks, CA: SAGE Publications.

Monk, M., \& Osborne, J. (1997). Placing the history and philosophy of science on the curriculum: A model for the development of pedagogy. Science Education, 81(4), 405-424. https://doi.org/10.1002/(SICI)1098-237X(199707)81:4<405::AID-SCE3>3.0.CO;2-G

Ozdemir, M. (2010). Nitel veri analizi: Sosyal bilimlerde yöntembilim sorunsalı üzerine bir çalışma [Qualitative data analysis: A study on methodology problem in social sciences]. Eskişehir Osmangazi University Journal of Social Sciences, 11(1), 323-343. Retrieved from http://dergipark.gov.tr/download/article-file/113287

Polat, M. (2011). Bilimin doğası hakkındaki görüşlerin kısa hikayeler yöntemiyle değerlendirilmesi: Fen bilgisi ögretmen adaylarl örneği [Assessing views about the nature of science by vignettes: The case of prospective science teachers] (PhD Thesis, Gazi University, Ankara).

Sert-Cibik, A. (2016). The effect of project-based history and nature of science practices on the change of nature of scientific information. International Journal of Environmental \& Science Education, 11(4), 453-472.

Tasar, M. F. (2002, September). Bilim hakkında görüşler anketi [Opinions about science survey]. V. Ulusal Fen Bilimleri ve Matematik Eğitimi Kongresi. ODTÜ, Ankara. Retrieved from http://144.122.59.41/ufbmek-5/ozetler/d307.pdf

Topdemir, H. G., \& Unat, Y. (2008). Bilim tarihi [History of science]. Ankara: Pegem Publications. https://doi.org/10.14527/9786055885021

Yenice, N., \& Atmaca, A. C. (2017). Fen bilgisi öğretmen adaylarının bilimin ve bilimsel bilginin doğasına yönelik bilgi ve görüşlerin belirlenmesi [Investigation of Preservice Science Teachers' Knowledge and Views about Nature of Science and Scientific Knowledge]. Journal of Theoretical Educational Science, 10(4), 366-393. https://doi.org/10.5578/keg.27943

Yildirim, A., \& Simsek H. (2013). Sosyal bilimlerde nitel araştırma yöntemleri [Qualitative research methods in the social sciences]. Ankara: Seçkin Publications.

Yildirim, C. (2006). Bilim tarihi [History of science]. İstanbul: Remzi Publications.

\section{Copyrights}

Copyright for this article is retained by the author(s), with first publication rights granted to the journal.

This is an open-access article distributed under the terms and conditions of the Creative Commons Attribution license (http://creativecommons.org/licenses/by/4.0/). 